\title{
Analisis Penerimaan Teknologi E-retribusi Pasar dengan Pendekatan Theory of Reasoned Action
}

\author{
Maria Magdalena $\mathrm{M}^{\mathrm{a}}$, Eko Sediyono ${ }^{\mathrm{b} *}$, Marwata $^{\mathrm{c}}$ \\ ${ }^{1}$ Magister Studi Pembangunan, Universitas Kristen Satya Wacana, Indonesia \\ ${ }^{2}$ Magister Sistem Informasi, Universitas Kristen Satya Wacana, Indonesia \\ ${ }^{3}$ Magister Akuntansi, Universitas Kristen Satya Wacana, Indonesia
}

Naskah Diterima : 20 Agustus 2018; Diterima Publikasi : 19 Oktober 2018

DOI : 10.21456/vol8iss2pp174-180

\begin{abstract}
The Trade Service The Salatiga City Government applies non-cash market retribution (market e-retribution) in improving the quality of services that are transparent and accountable in traditional markets. Given that there has been no research discussing the acceptance of market e-retribution technology, this issue can be an interesting topic to study. Theory of Reasoned Action (TRA) is used as a conceptual model in this study with the aim of investigating the factors that influence the acceptance of market e-retribution technology in traditional market traders in the city of Salatiga. The results of this study indicate that perceptions of usefulness, perception of self-efficacy and subjective norms have a positive effect, but are not statistically significant, while perceptions of compatibility and attitude have a positive and statistically significant effect.
\end{abstract}

Keywords : E-retribution Market; TRA; Technology Acceptance; PLS

\begin{abstract}
Abstrak
Dinas Perdagangan Pemerintah Kota Salatiga menerapkan retribusi pasar secara non tunai (e-retribusi pasar) dalam meningkatkan kualitas pelayanan yang transparan dan akuntabel di pasar tradisional. Mengingat belum ada penelitian yang membahas mengenai penerimaan teknologi e-retribusi pasar, maka isu ini dapat menjadi topik yang menarik untuk diteliti. Theory of Reasoned Action (TRA) digunakan sebagai model konseptual di dalam penelitian ini dengan tujuan menyelidiki faktor-faktor yang mempengaruhi penerimaan teknologi e-retribusi pasar pada pedagang pasar tradisional di kota Salatiga. Hasil penelitian ini menunjukkan bahwa persepsi kegunaan, persepsi kemampuan diri dan norma subyektif berpengaruh positif, namun secara statistik tidak signifikan, sedangkan persepsi kesesuaian dan sikap berpengaruh positif dan secara statistik signifikan.
\end{abstract}

Kata kunci: E-retribusi Pasar; TRA; Penerimaan Teknologi; PLS

\section{Pendahuluan}

Seiring dengan perkembangan teknologi di bidang sistem pembayaran, transaksi non tunai sudah merupakan sebuah keniscayaan. Kebijakan transaksi non tunai menjadi strategi yang efektif untuk mendorong pertumbuhan keuangan inklusif di Indonesia. Penerapan transaksi non tunai diyakini sebagai salah satu solusi pemberantasan korupsi dan pencucian uang sebab melalui proses transaksi mutasi kas yang sistematis dan lengkap, antara pihak pengirim dan penerima, sehingga peluang oknum melakukan tindak kejahatan semakin sempit.

Sistem e-retribusi pasar yang diterapkan Dinas Perdagangan Kota Salatiga merupakan solusi kebutuhan akan sistem pemantauan mulai dari proses pendaftaran, proses penetapan, proses penyetoran dan proses pelaporan untuk meraih Pendapatan Asli

\footnotetext{
*) Penulis korespondensi: eko@uksw.edu
}

Daerah (PAD) secara optimal dan tidak lagi dikelola secara manual. E-retribusi pasar dimaksudkan dan ditujukan Pemerintah Kota Salatiga, diantaranya: i) menyelenggarakan tertib administrasi pengelolaan retribusi dengan cara pemungutan dan pembayaran retribusi pasar secara eletronik; ii) meminimalisir penyimpangan penarikan retribusi pasar; iii) efisiensi pengelolaan retribusi pelayanan pasar; iv) membangun kesadaran untuk bertanggung jawab terhadap kewajiban; v) mewujudkan "Salatiga Smart City". Manfaat e-retribusi pasar bagi pedagang pasar tradisional adalah mempermudah melakukan pembayaran retribusi pasar menggunakan kartu elektronik dengan media penarikan biaya melalui alat EDC (Electronic Data Capture). Selain itu, pelaporan data transaksi akuntabel dan realtime incoming report. 
Mengingat belum ada penelitian sebelumnya mengenai penerimaan teknologi e-retribusi pasar, maka penelitian ini dilakukan dengan tujuan menyelidiki penerimaan teknologi e-retribusi pasar dengan pendekatan Theory of Reasoned Action (TRA) yang dikemukakan oleh Fang et al. (2017).

\section{Kerangka Teori}

\subsection{Theory of Reasoned Action (TRA)}

Fang, et al. (2017) menjelaskan intensi (behavior intention) seseorang untuk melakukan suatu perilaku tertentu dipengaruhi oleh sikap (attitude) dan norma subyektif (subjective norm). Sikap cenderung memberikan penilaian suka atau tidak suka terhadap objek serta mencerminkan perasaan seseorang terhadap sesuatu. Sedangkan, norma subyektif merupakan persepsi individu berhubungan dengan orang-orang yang penting bagi dirinya yang mengharapkannya untuk melakukan atau tidak melakukan suatu perilaku tertentu, kemudian orangorang yang penting itu dijadikan acuan atau patokan untuk mengarahkan perilaku (Gambar 1).

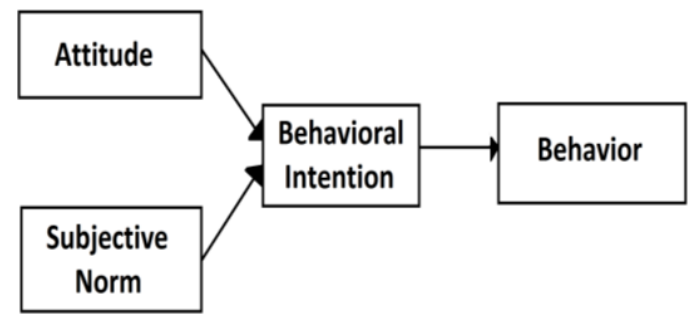

Gambar 1. Model TRA

Model TRA telah digunakan dalam penelitianpenelitian sebelumnya tentang penerimaan teknologi (Nor et al. 2008; Shih dan Fang, 2011; Al-Ajam dan Md Nor, 2013). Kemudian untuk keperluan tujuan penelitian ini, maka TRA dimodifikasi dengan menambah konstruk-konstruk yang diduga mempengaruhi sikap (Gambar 2). Penelitian ini mengadaptasi pengukuran-pengukuran dari penelitian tentang penerimaan teknologi terdahulu sebagai konstruk laten eksogen, yaitu persepsi kegunaan oleh Davis (1989), persepsi kemampuan diri menggunakan teknologi oleh Olivia (2001) serta persepsi kesesuaian teknologi oleh La Morte (2018), yang berpengaruh terhadap konstruk endogen sikap.

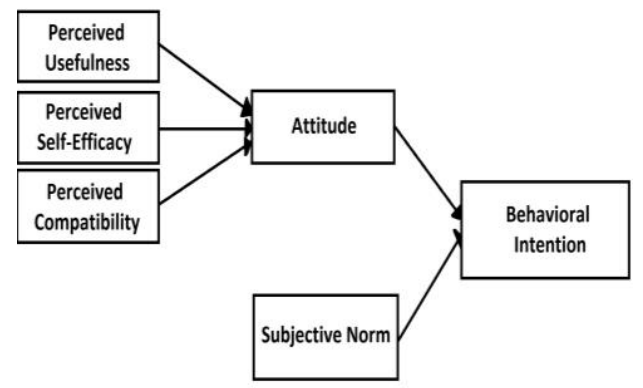

Gambar 2. Model penelitian

\subsection{Faktor-faktor dalam Penerimaan Sistem Transaksi}

Manfaat dalam menggunakan uang elektronik merupakan nilai kegunaan yang akan diperoleh atau diharapkan oleh penggunanya dalam melakukan berbagai transaksi dengan uang elektronik (Priambodo dan Prabawani, 2016). Seseorang akan melihat manfaat kegunaan uang elektronik, memungkinkan mereka untuk melakukan proses pembayaran lebih cepat dan lebih praktis dibandingkan dengan uang kartal. Secara empiris pengaruh faktor persepsi kegunaan (perceived usefulness) telah dibuktikan dalam penelitian Li et al. (2014) dan $\mathrm{Tu}$ et al. (2011) yang menunjukkan konstruk kegunaan memiliki pengaruh yang signifikan.

Kemampuan diri mengacu pada perasaan diri individu, terbawa dengan keyakinan bahwa individu tersebut dapat menyelesaikan tugas yang diberikan, dan lebih luas lagi mengatasi tantangan hidup (Farrell et al. 2016). Seseorang dengan pandangan kemampuan diri (perceived self-efficacy) rendah akan menganggap sulit sebuah tugas atau pekerjaan yang diberikan padanya (Bandura, 2016). Sekalipun prospeknya transaksi menggunakan uang elektronik menawarkan manfaat, namun jika seseorang tidak yakin dengan kemampuan dirinya, orang tersebut mungkin tidak mau menggunakannya, sebaliknya kemampuan diri seseorang tinggi akan mudah menggunakannya. Penelitian yang dilakukan Ali et al. (2015) serta Lule (2011) menunjukkan faktor kemampuan diri memiliki pengaruh yang signifikan.

Persepsi kesesuaian adalah kecocokan dan kekonsistenan suatu inovasi produk akan ide-ide, nilai, kepercayaan, pengalaman masa lalu dan kebutuhan saat ini (Laksana et al., 2015). Inovasi transaksi non tunai yang dirasa sesuai (perceived compatibility) dengan kebutuhan dan situasi serta kondisi lingkungan sosial saat ini, akan mudah diadopsi seseorang, bilamana tidak maka sebaliknya akan sulit. Penelitian yang dilakukan Li et al. (2014) serta Schierz et al. (2010) menunjukkan faktor kesesuaian memiliki pengaruh yang signifikan.

Berdasarkan model penelitian (Gambar 2), hipotesis penelitian yang diajukan sebagai berikut: H1: Persepsi kegunaan (PU) berpengaruh positif terhadap sikap (AT).

H2: Persepsi kemampuan diri (PSE) berpengaruh positif terhadap sikap (AT).

H3: Persepsi kesesuaian (PC) berpengaruh positif terhadap sikap (AT).

H4: Sikap (AT) berpengaruh positif terhadap intensi menggunakan e-retribusi pasar (BI).

H5: Norma subyektif (SN) berpengaruh positif terhadap intensi menggunakan e-retribusi pasar (BI).

Berikut model yang menggambarkan hubungan antar konstruk dalam penelitian ini dari kelima hipotesis yang diusulkan pada Gambar 3 . 


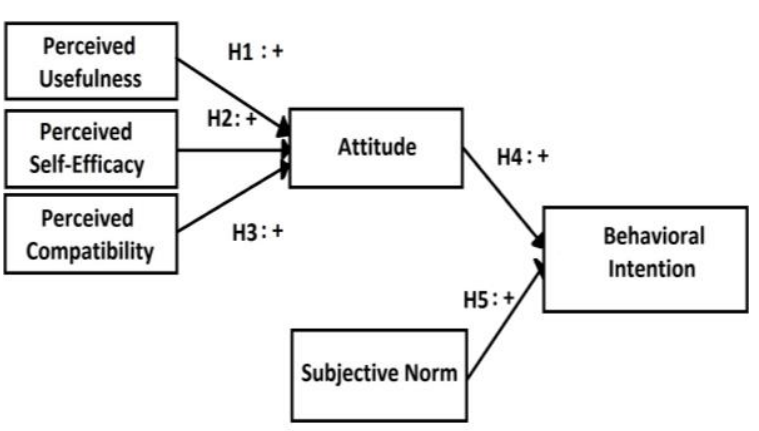

Gambar 3. Hubungan antar konstruk laten

\section{Metode}

Penelitian ini merupakan penelitian kuantitatif dengan melakukan survei. Survei adalah metode pengambilan data sampel dari suatu populasi dengan menggunakan kuesioner sebagai alat yang pokok dalam pengumpulan data (Nazir, 2013). Teknik purposive sampling digunakan untuk menentukan sampel dengan pertimbangan tertentu berupa kriteria yang harus dipenuhi setiap anggota populasi yang akan dijadikan sampel. Hal ini sebab kemungkinan perbedaan persepsi antara peneliti dan responden berkaitan dengan pertanyaan-pertanyaan yang diajukan tidak dapat dihindari, meskipun hal ini sudah diusahakan untuk diminimalisasi dalam proses penyusunan kuesioner.

Populasi dalam penelitian ini adalah pedagang di pasar Blauran I yang diimplementasikan e-retribusi pasar berjumlah 790 pedagang yang terdata di kantor Dinas Perdagangan Kota Salatiga. Jumlah sampel dalam penelitian ini menggunakan rumus menghitung ukuran sampel dari populasi yang dikemukakan oleh Isaac dan Michael (Sugiyono, 2010) dengan taraf kesalahan 5\%. Rumus menghitung ukuran sampel tersebut adalah pada persamaan (1) berikut:

$\mathrm{S}=\lambda^{2} * \mathrm{~N} * \mathrm{P} * \mathrm{Q} / \mathrm{d}^{2}(\mathrm{~N}-1)+\lambda^{2} * \mathrm{P} * \mathrm{Q}$ dimana:

$\mathrm{S}=$ Jumlah sampel

$\lambda^{2}=$ Nilai tabel $\mathrm{chi}^{2}$

$\mathrm{N}=$ Jumlah anggota populasi

$\mathrm{P}=$ Proposi dalam populasi

$\mathrm{Q}=1$ - Proporsi dalam populasi

$\mathrm{d}^{2}=$ Taraf kesalahan $(5 \%)$

Analisis penelitian ini menggunakan Partial Least Squares (PLS) menggunakan SmartPLS 3.0. dengan tipe indikator reflektif, terdiri dari 3 indikator reflektif konstruk persepsi kegunaan (PU), 4 indikator reflektif konstruk persepsi kemampuan diri (PSE), 3 indikator reflektif konstruk persepsi kesesuaian (PC), 3 indikator reflektif konstruk sikap (AT), 2 indikator reflektif konstruk norma subyektif (SN) dan 3 indikator reflektif konstruk niat perilaku (BI).

\section{Hasil dan Pembahasan}

Hasil perhitungan ukuran sampel dengan rumus Isaac dan Michael memperoleh jumlah sampel sebanyak 88 , namun dalam penelitian ini responden yang memenuhi kriteria peneliti adalah sebanyak 31 . Jumlah 31 responden yang diperoleh bisa digunakan dalam penelitian ini didukung syarat analisis menggunakan PLS, yang memiliki kriteria ukuran sampel 30-100 (Latan dan Ghozali, 2012).

Penelitian ini memperoleh jumlah 31 responden yang terdiri dari 7 pedagang laki-laki $(22,59 \%)$ dan 24 pedagang perempuan $(77,41 \%)$, dengan usia responden dari usia 21-30 sebanyak 3 responden $(9,68 \%)$, usia $31-40$ sebanyak 8 responden $(25,80 \%)$, usia $41-50$ sebanyak 7 responden $(22,59 \%)$, usia $51-$ 60 sebanyak 9 responden $(29,03 \%)$, usia $61-70$ sebanyak 2 responden $(6,46 \%)$ dan usia lebih dari 70 tahun sebanyak 2 responden $(6,46 \%)$. Selain itu, jenis usaha responden terdiri dari 9 pedagang sayur-mayur $(29,03 \%), 3$ pedagang buah $(9,68 \%), 7$ pemilik toko kelontong $(22,59 \%), 2$ pedagang makanan ringan $(6,46 \%), 2$ pemilik warung makan $(6,46 \%), 2$ pedagang tempe $(6,46 \%)$ dan 6 jenis usaha lainnya $(19,36 \%)$.

Hasil uji validitas konvergen menunjukkan tiga indikator reflektif dari konstruk persepsi kemampuan diri (PSE), yakni PSE1, PSE2, PSE3 dan satu indikator reflektif dari konstruk norma subyektif $(\mathrm{SN})$, yakni SN2 memiliki ukuran indikator reflektif yang rendah $(<0,70)$, atau tidak memenuhi syarat validitas konvergen. Ukuran indikator reflektif dikatakan tinggi jika berkorelasi $>0,70$ dengan variabel yang diukur, maka indikator-indikator tersebut dihapus dari model penelitian ini, kemudian data diolah kembali, sehingga hasil uji dapat memenuhi standar validitas konvergen (Tabel 1). Apabila terjadi perubahan pada indikator, hal ini tidak akan berakibat mengubah makna konstruk laten, atau dengan kata lain validitas konstruk laten tidak akan berubah jika ada indikator yang dihilangkan (Latan dan Ghozali, 2012).

Tabel 1. Pengujian loading factor validitas

\begin{tabular}{|c|c|c|c|c|c|c|}
\hline & BI & $\overline{\mathrm{SN}}$ & PSE & PU & $\mathrm{PC}$ & AT \\
\hline AT1 & & & & & & 0,982 \\
\hline AT2 & & & & & & 0,995 \\
\hline AT3 & & & & & & 0,987 \\
\hline BI1 & 0,981 & & & & & \\
\hline BI2 & 0,993 & & & & & \\
\hline BI3 & 0,987 & & & & & \\
\hline PC1 & & & & & 0,972 & \\
\hline PC2 & & & & & 0,985 & \\
\hline PC3 & & & & & 0,966 & \\
\hline PSE4 & & & 1,000 & & & \\
\hline PU1 & & & & 0,820 & & \\
\hline PU2 & & & & 0,886 & & \\
\hline PU3 & & & & 0,859 & & \\
\hline SN1 & & 1,000 & & & & \\
\hline
\end{tabular}


Hasil uji validitas diskriminan menunjukkan korelasi konstruk laten memprediksi indikator pada blok sendiri lebih baik dibanding pada blok konstruk laten yang lain (Tabel 2). Selain itu, validitas diskriminan yang diukur dengan membandingkan nilai average variance extracted (AVE), menunjukkan nilai AVE > 0,5 (Tabel 3).

Tabel 2. Pengujian cross loading validitas diskriminan

\begin{tabular}{|c|c|c|c|c|c|c|}
\hline & BI & $\mathrm{SN}$ & PSE & $\mathrm{PU}$ & $\mathrm{PC}$ & AT \\
\hline AT1 & 0,926 & 0,787 & 0,354 & 0,522 & 0,742 & 0,982 \\
\hline AT2 & 0,945 & 0,765 & 0,339 & 0,483 & 0,738 & 0,995 \\
\hline AT3 & 0,926 & 0,757 & 0,295 & 0,462 & 0,726 & 0,987 \\
\hline BI1 & 0,981 & 0,762 & 0,279 & 0,582 & 0,675 & 0,948 \\
\hline BI2 & 0,993 & 0,788 & 0,307 & 0,547 & 0,712 & 0,932 \\
\hline BI3 & 0,987 & 0,803 & 0,339 & 0,597 & 0,680 & 0,912 \\
\hline PC1 & 0,668 & 0,602 & 0,305 & 0,378 & 0,972 & 0,726 \\
\hline PC2 & 0,681 & 0,598 & 0,329 & 0,390 & 0,985 & 0,719 \\
\hline PC3 & 0,690 & 0,600 & 0,301 & 0,370 & 0,966 & 0,731 \\
\hline PSE4 & 0,312 & 0,328 & 1,000 & 0,307 & 0,320 & 0,333 \\
\hline PU1 & 0,440 & 0,483 & 0,126 & 0,820 & 0,127 & 0,376 \\
\hline PU2 & 0,440 & 0,382 & 0,192 & 0,886 & 0,261 & 0,341 \\
\hline PU3 & 0,580 & 0,521 & 0,410 & 0,859 & 0,531 & 0,513 \\
\hline SN1 & 0,795 & 1,000 & 0,328 & 0,551 & 0,616 & 0,779 \\
\hline
\end{tabular}

Tabel 3. Nilai AVE

\begin{tabular}{ll}
\hline \multicolumn{1}{c}{ Konstruk Laten } & AVE \\
\hline Intensi (BI) & 0,974 \\
Norma Subyektif (SN) & 1,000 \\
Persepsi Kemampuan Diri (PSE) & 1,000 \\
Persepsi Kegunaan (PU) & 0,732 \\
Persepsi Kesesuaian (PC) & 0,949 \\
Sikap (AT) & 0,976 \\
\hline
\end{tabular}

Uji reliabilitas menggunakan tolok ukur composite reliability dan cronbach's alpha dengan nilai minimal 0,70, maka diperoleh hasil uji konstruk laten berada di atas 0,70 atau alat ukur dinyatakan reliabel (Tabel 4). Nilai terendah composite reliability sebesar 0,891 dan nilai terendah cronbach's alpha sebesar 0,821 pada konstruk persepsi kegunaan (PU), namun masih di atas syarat uji reliabilitas yang ditetapkan.

Tabel 4. Pengujian composite reliability dan cronbach's alpha

\begin{tabular}{lcc}
\hline \multicolumn{1}{c}{ Konstruk Laten } & $\begin{array}{c}\text { Cronbach's } \\
\text { Alpha }\end{array}$ & $\begin{array}{c}\text { Composite } \\
\text { Reliability }\end{array}$ \\
\hline Intensi (BI) & 0,987 & 0,991 \\
Norma Subyektif (SN) & 1,000 & 1,000 \\
Persepsi Kemampuan Diri (PSE) & 1,000 & 1,000 \\
Persepsi Kegunaan (PU) & 0,821 & 0,891 \\
Persepsi Kesesuaian (PC) & 0,973 & 0,982 \\
Sikap (AT) & 0,988 & 0,992 \\
\hline
\end{tabular}

Kemudian untuk mengukur kecocokkan model (model-fit) penelitian ini, terdapat kriteria pada analisis jalur PLS yang dapat mewakili penilaian terhadap suatu model yang mengindikasikan kesesuaian atau model penelitian dianggap cocok. Dalam penelitian ini menggunakan ukuran kecocokkan model Standardized Root Mean Square Residual (SRMSR). SRMSR mengkuantifikasi seberapa kuat matriks korelasi empiris dibandingkan dengan matriks korelasi tersirat, atau dengan kata lain SRMSR menilai besar korelasi model yang teramati (Saturated Model) dan besar korelasi model yang diharapkan (Estimation Model) yang dianggap sesuai atau cocok. Umumnya perolehan nilai 0 pada SRMSR menunjukkan sebuah kecocokkan model yang sempurna (Byrne 2008, dalam Henseler et al. 2016), sementara nilai $<0,10$ atau $0,08(\mathrm{Hu}$ dan Bentler 1999, dalam Henseler et al. 2016; Ramayah et al. 2017; Machado, 2017) dianggap cocok. Dalam penelitian ini nilai SRMSR menunjukkan Saturated Model adalah 0,069 dari Estimation Model sebesar 0,090, maka model penelitian ini dianggap memenuhi kriteria kecocokkan model SRMSR, yaitu $<0,10$ atau 0,08 .

Hasil $\mathrm{R}^{2}$ model struktural penelitian ini menunjukkan konstruk laten endogen intensi (BI) memperoleh nilai $\mathrm{R}^{2}$ sebesar 0,899 yang berarti pengaruh konstruk eksogen norma subyektif (SN) dan sikap (AT) terhadap niat perilaku (BI) di dalam penelitian ini sebesar $89,9 \%$ dan sisanya $10,1 \%$ dijelaskan oleh konstruk laten lain di luar yang diteliti. Sedangkan, konstruk endogen sikap (AT) menghasilkan nilai $\mathrm{R}^{2}$ sebesar 0,607 yang berarti pengaruh konstruk eksogen persepsi kegunaan (PU), persepsi kemampuan diri (PSE) dan persepsi kesesuaian (PC) terhadap konstruk endogen sikap (AT) sebesar $60,7 \%$ dan sisanya 39,3\% dijelaskan oleh konstruk laten lain di luar yang diteliti (Tabel 5).

Tabel 5. $\mathrm{R}^{2}$

\begin{tabular}{lc}
\hline \multicolumn{1}{c}{ Konstruk Laten } & $\mathrm{R}^{2}$ \\
\hline Intensi (BI) & 0,899 \\
Sikap (AT) & 0,607 \\
\hline
\end{tabular}

Evaluasi model untuk mengukur nilai signifikansi dilihat dari $t$-statistik $>t$-tabel dengan nilai $t$ sebesar 1,96 ( $t$ tabel significance 5\% = 1,96). Berikut hasil uji $t$-statistik penelitian ini dari path coefficients pada Tabel 6 dan model struktural $\mathrm{R}^{2}$ pada Gambar 4.

Tabel 6. Path coefficients

\begin{tabular}{lccccc}
\hline & Estimasi & Mean & $\begin{array}{c}\text { Standar } \\
\text { Deviasi }\end{array}$ & $\begin{array}{c}t \text { - } \\
\text { Statistik }\end{array}$ & $\begin{array}{c}\text { Nilai } \\
\text { P }\end{array}$ \\
\hline $\begin{array}{l}\text { SN } \\
->\mathrm{BI}\end{array}$ & 0,152 & 0,160 & 0,133 & 1,140 & 0,255 \\
$\begin{array}{l}\text { PSE } \\
->\text { AT }\end{array}$ & 0,059 & 0,062 & 0,129 & 0,459 & 0,646 \\
$\begin{array}{l}\text { PU } \\
->\text { AT }\end{array}$ & 0,230 & 0,233 & 0,144 & 1,589 & 0,113 \\
$\begin{array}{l}\text { PC } \\
->\text { AT }\end{array}$ & 0,636 & 0,627 & 0,142 & 4,494 & 0,000 \\
$\begin{array}{l}\text { AT } \\
\rightarrow \text { BI }\end{array}$ & 0,825 & 0,819 & 0,128 & 6,424 & 0,000 \\
\hline
\end{tabular}




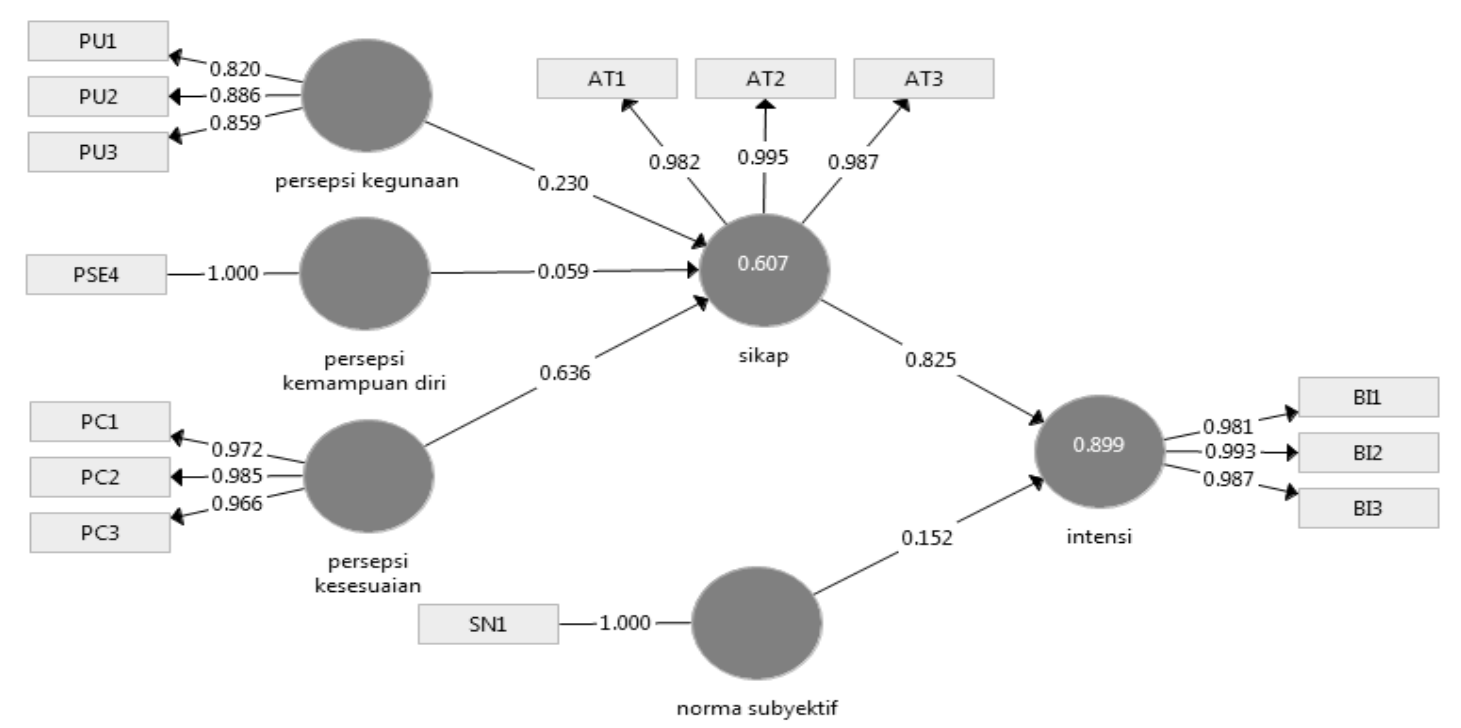

Gambar 4. Estimasi nilai $t$ dan output $\mathrm{R}^{2}$ model struktural

Berdasarkan analisis model struktural melalui hasil uji signifikansi hipotesis menunjukkan dua hipotesis penelitian ini diterima dan tiga hipotesis penelitian ini ditolak yang tercantum pada Tabel 7 .

Tabel 7. Hasil uji signifikansi hipotesis

\begin{tabular}{lllc}
\hline & Jalur & Hasil Uji & Keterangan \\
\hline H1 & SN $\rightarrow$ BI & $1,140(<1,96)$ & Ditolak \\
H2 & PSE $\rightarrow$ AT & $0,459(<1,96)$ & Ditolak \\
H3 & PU $\rightarrow$ AT & $1,589(<1,96)$ & Ditolak \\
H4 & PC $\rightarrow$ AT & $4,494(>1,96)$ & Diterima \\
H5 & AT $\rightarrow$ BI & $6,424(>1,96)$ & Diterima \\
\hline
\end{tabular}

Konstruk Persepsi kegunaan menunjukkan tidak memiliki pengaruh yang signifikan terhadap sikap sebesar $1,589(<1,96)$, meskipun dalam penelitian ini terdapat hubungan positif antara persepsi kegunaan dan sikap sebesar 0,230, namun hipotesis penelitian ini secara statistik ditolak (Tabel 7). Hal ini mengindikasikan apabila persepsi seseorang mengenai kegunaan rendah, maka sikap orang tersebut terhadap penggunaan retribusi pasar rendah, yang berarti tidak terdapat hubungan yang kuat antara persepsi kegunaan dan sikap. Hasil penelitian ini tidak sejalan dengan penelitian yang dilakukan $\mathrm{Li}$ et al. (2014) dan Tu et al. (2011), yang menunjukkan persepsi kegunaan memiliki pengaruh yang signifikan terhadap sikap, namun kemungkinan dampak dari penerapan e-retribusi pasar dalam jangka waktu pendek belum terlihat karena baru tahun 2018 sistem e-retribusi pasar berjalan di Pasar Baluran I.

Konstruk Persepsi kemampuan diri menunjukkan tidak memiliki pengaruh yang signifikan terhadap sikap sebesar $0,459(<1,96)$, serta dalam penelitian ini tidak terdapat hubungan positif antara persepsi kemampuan diri dan sikap sebesar 0,059, maka penelitian ini secara hipotesis dan statistik ditolak (Tabel 7). Hal ini mengindikasikan apabila persepsi seseorang mengenai kemampuan dirinya rendah, maka sikap orang tersebut terhadap penggunaan eretribusi pasar rendah, yang berarti tidak terdapat hubungan yang kuat antara persepsi kemampuan diri dan sikap. E-retribusi pasar sesungguhnya tidak menyulitkan pedagang di Pasar Baluran I untuk melakukan pembayaran retribusi pasar dengan eretribusi pasar, namun kemungkinan mindset responden yang terbiasa dengan pembayaran manual akan dirasa sulit untuk terbiasa berperilaku membayar retribusi pasar dengan e-retribusi pasar. Hasil penelitian ini sesuai pernyataan Bandura (2016), namun tidak sejalan dengan penelitian yang dilakukan Ali et al. (2015) serta Lule (2011) yang menunjukkan faktor kemampuan diri memiliki pengaruh yang signifikan.

Konstruk Persepsi kesesuaian menunjukkan memiliki pengaruh yang signifikan terhadap sikap sebesar 4,494 (> 1,96), serta terdapat hubungan positif antara persepsi kesesuaian dan sikap sebesar 0,636, maka hipotesis penelitian ini secara statistik diterima (Tabel 7). Hal ini mengindikasikan apabila persepsi seseorang mengenai kesesuaian tinggi, maka sikap orang tersebut terhadap penggunaan e-retribusi pasar tinggi, yang berarti terdapat hubungan yang kuat antara persepsi kesesuaian dan sikap. Selain itu pembayaran retribusi pasar secara non tunai dirasa sesuai dengan situasi dan kondisi lingkungan sosial saat ini. Hasil penelitian ini sejalan dengan penelitian Schierz et al. (2010) serta Li et al. (2014) yang menunjukkan konstruk kesesuaian terbukti mempengaruhi sikap.

Konstruk Sikap menunjukkan memiliki pengaruh yang signifikan terhadap niat perilaku sebesar 6,424 $(>1,96)$, serta terdapat hubungan positif antara sikap dan niat perilaku sebesar 0,825, maka hipotesis penelitian ini secara statistik diterima (Tabel 7). Hal ini mengindikasikan apabila semakin tinggi sikap, maka akan menyebabkan semakin tinggi niat perilaku dalam menggunakan e-retribusi pasar, yang 
berarti terdapat hubungan yang kuat antara sikap dan niat perilaku. Hasil penelitian ini sejalan dengan teori dan penelitian yang dilakukan Fang et.al, (2017) yang menyatakan sikap terhadap perilaku merupakan salah satu faktor penentu terbentuknya niat.

Konstruk Norma subyektif menunjukkan tidak memiliki pengaruh yang signifikan terhadap niat perilaku sebesar 1,140 (< 1,96), meskipun dalam penelitian ini terdapat hubungan positif antara norma subyektif dan niat perilaku sebesar 0,152 , namun hipotesis penelitian ini secara statistik ditolak (Tabel 7). Hal ini mengindikasikan apabila norma subyektif rendah, maka akan menyebabkan niat perilaku dalam menggunakan e-retribusi pasar rendah, yang berarti tidak terbukti benar adanya hubungan yang kuat antara norma subyektif dan niat perilaku. Hasil penelitian ini menjelaskan bahwa tidak ada acuan atau patokan responden terhadap social referent atau orang-orang yang dianggap penting yang mempengaruhi responden terhadap niat perilaku untuk menggunakan e-retribusi pasar. Selain itu penerapan e-retribusi pasar merupakan suatu kebijakan pemerintah Kota Salatiga yang bersifat wajib. Hasil penelitian ini tidak sejalan dengan teori dan penelitian yang dilakukan Fang et al. (2017) yang menyatakan melakukan atau tidak melakukan suatu perilaku salah satunya dipengaruhi oleh norma subyektif.

\section{Kesimpulan}

Penelitian ini menunjukkan bahwa penerimaan teknologi e-retribusi pasar pada responden pedagang di Pasar Blauran I, cenderung memberikan penilaian individual yang positif melalui sikap dalam merespon teknologi e-retribusi pasar, karena e-retribusi pasar dipersepsikan memiliki kesesuaian teknologi dalam pembayaran retribusi pasar secara non tunai, yang dirasa sesuai dengan situasi dan kondisi lingkungan sosial saat ini. Sikap menunjukkan pengaruh yang signifikan terhadap intensi penggunaan e-retribusi pasar untuk melakukan pembayaran retribusi pasar secara non tunai menggunakan kartu elektronik (kartu e-retribusi). Akan tetapi, berdasarkan statistik menunjukkan konstruk persepsi kegunaan dan konstruk persepsi kemampuan diri tidak memiliki pengaruh yang signifikan, serta konstruk norma subyektif secara statistik juga tidak menunjukkan pengaruh yang signifikan terhadap intensi penggunaan e-retribusi pasar, maka hipotesis konstruk persepsi kegunaan, konstruk persepsi kemampuan diri, dan norma subyektif secara statistik ditolak.

Untuk keberlanjutan penelitian ini dapat mengembangkan model penelitian dengan teori-teori atau variabel-variabel tentang penerimaan teknologi atau menyelidiki faktor-faktor lain dalam penelitian ini sebesar $10,1 \%$ yang mempengaruhi niat perilaku penggunaan e-retribusi pasar dan yang mempengaruhi sikap pedagang sebesar 39,3\% di luar model yang diteliti. Kemudian keterbatasan penelitian ini adalah memiliki jumlah responden yang sedikit, dikarenakan terdapat responden pedagang yang tidak memenuhi kriteria yang ditetapkan peneliti dalam penelitian ini, maka untuk penelitian selanjutnya menambahkan kuota sampel yang lebih banyak. Diharapkan penelitian ini juga dapat menjadi acuan untuk penelitian tentang eretribusi pasar di kota-kota lain yang sudah diterapkan sistem serupa.

\section{Daftar Pustaka}

Al-Ajam, A.S., Md Nor, K., 2013. Predicting internet banking adoption determinants in yemen using extended theory of reasoned action. Research Journal of Applied Sciences 8 (5), 278-285.

Ali, M., Chin-Hong, P., Arif I., 2015. Determinants of e-banking adoption: A non-users perspective in Pakistan. MPRA Paper (Munich Personal RePEc Archive), Munich University Library, Germany.

Bandura, A., 2016. Self Efficacy for Agentic Positive Psychology. Encyclopedia of human behavior 4, 71-81. New York: Academic Press.

Davis, F. D., 1989. Perceived usefulness, perceived ease of use, and user acceptance of information technology. MIS Quarterly 13(3), 319-340.

Fang, Wei-Ta, 2017. Normative Beliefs, Attitudes, and Social Norms: People Reduce Waste as an Index of Social Relationships When Spending Leisure Time. Sustainability 2017, 9, 1696;doi:10.3390/su9101696 diakses dari: http:// www.mdpi.com/journal/sustainability

Farrell, L., Fry, T.R.L., Risse, L., 2016. The significance of financial self-efficacy in explaining women's personal finance behavior. Journal of Economic Psychology 54, 85-99.

García-Machado, J., 2017. Assessing A Moderating Effect and The Global Fit of A PLS Model on Online Trading. Department of Financial Economics, Accounting and Operations Management University of Huelva, Spain.

Henseler, J., Hubona, G., Ash Ray, P., 2016. Using PLS path modeling in new technology research: updated guidelines. Industrial Management and Data Systems 116 (1), 2-20.

Laksana, G.B., Astutik, E.S., Dewantara R.Y., 2015. Pengaruh persepsi kemanfaatan, persepsi kemudahan penggunaan, persepsi resiko dan persepsi kesesuaian terhadap minat menggunakan mobile banking. Jurnal Administrasi Bisnis (JAB), Fakultas Ilmu Administrasi, Universitas Brawijaya 26 (2).

La Morte, Wayne W. 2018. Diffusion of Innovation Theory. Behavioral Change Models. diakses 
dari: $\quad$ http://sphweb.bumc.bu.edu/otlt/MPHModules/SB/BehavioralChangeTheories/Behavi oralChangeTheories4.html.

Latan, H., Ghozali, I., 2012. Partial Least Squares Konsep, Teknik dan Aplikasi SmartPLS 2.0. Semarang: Badan Penerbit Universitas Diponegoro.

Li, J., Liu, J.L., Ji, H.Y., 2014. Empirical study of influence factors of adaption intention of mobile payment based on TAM model in China. International Journal of $\mathrm{u}$ - and e- Service, Science and Technology 7(1), 119-132.

Lule, I., 2011. Application Technology Acceptance Model in Mobile Banking Adoption in Kenya. School of Computing and Informatics University of Nairobi, Kenya.

Nazir, Moh., 2013. Metode Penelitian. Jakarta: Balai Aksara.

Nor, K., Abu-Shanab, E., Pearson, J., 2008. Internet banking acceptance in Malaysia based on the theory of reasoned action. Journal of Information Systems and Technology Management 5(1).

Olivia Khorrami-Arani, 2001. Researching computer self-efficacy. International Education Journal Vol 2, No 4, 2001. Educational Research Conference 2001 Special Issue. diakses dari: http://www.flinders.edu.au/education/iej
Priambodo, S., Prabawani, B., 2016. Pengaruh persepsi manfaat, persepsi kemudahan penggunaan, dan persepsi resiko terhadap minat menggunakan layanan uang elektronik (studi kasus pada masyarakat di kota Semarang). Jurnal Ilmu Administrasi Bisnis, Fakultas Ilmu Sosial dan Ilmu Politik, Universitas Diponegoro 5(2), 127-135.

Ramayah, T., Yeap, Jasmine A.L., Ahmad, Noor H., Halim, Hasliza A., Rahman, Syed A., 2017. Testing a confirmatory model of facebook usage in smartpls using consistent PLS. International Journal of Business and Innovation 3(2), 01-14.

Schierz, P.G., Schilke, O., Wirtz, B., 2010. Understanding consumer acceptance of mobile payment services: an empirical analysis (june 5, 2009). Electronic Commerce Research and Applications 9(3), 209-216.

Sugiyono, 2010. Metode Penelitian Pendidikan Pendekatan Kuantitatif, kualitatif, dan R\&D (cet. 11). Bandung: Alfabeta.

Tu, T.T., Chang, H. H., Chiu, Y.H., 2011. Investigation of the factors influencing the acceptance of electronic cash stored-value cards. African Journal of Business Management 5(1), 108-120. 